\title{
Influence of Environmental Risk on the Financial Structure of Oil and Gas Projects
}

\author{
${ }^{1}$ Alberto De Marco and ${ }^{2}$ Bagilya Karsybayeva \\ ${ }^{1}$ Department of Management and Production Engineering, \\ Politecnico di Torino, Corso Duca degli Abruzzi 24, 10129 Turin, Italy \\ ${ }^{2}$ COSMI Kazakhstan LLP, Astana, Republic of Kazakhstan, A. Baitursynova Street, Block A-2, Highvill
}

Received 2012-09-15, Revised 2013-03-08; Accepted 2013-03-12

\begin{abstract}
The risk profile of a Build-Operate-Transfer (BOT) project affects its debt service ability. In particular, the total risk profile of an oil and gas project is heavily influenced by its environmental risk exposure. However, this risk is often not given a considerable weight in risk analysis, resulting in underestimation of project's total riskiness and consequent overestimation of the debt capacity. This study is aimed at understanding the dependence of the capital structure of oil and gas BOT projects on environmental risk exposure and proposes a methodology for incorporating such important risk into the total risk rating process to determine the debt leverage. As a result, it is shown that integrating environmental risks into the risk score of a project yields higher values of risk exposure, which may lead to a lower debt-to-equity ratio.
\end{abstract}

Keywords: Environmental Risk, Oil and Gas, Project Financing, Project Management, Risk Assessment, Risk Rating

\section{INTRODUCTION}

Project Financing (PF) has emerged as a distinct way of funding large international high risk projects and has undergone a drastic growth over the last decades. Under the terms of a PF mechanism, one or more investors join a separate legal entity, often called Special Purpose Vehicle (SPV), to finance design, construction, operations and maintenance of an infrastructure for a specified government-granted concession period. The initial investment, funded by means of both equity and debt sources, is intended to be recovered through revenues from the service provided during the concession period, which is determined to sufficiently pay off the debt incurred and earn an acceptable profit from the project cash flows (Zhang, 2009). This mechanism is often termed as a Build-Operate and Transfer (BOT) form of contract to develop a PublicPrivate Partnership (PPP).

Construction projects are highly exposed to a variety or risks. Moreover, risk plays an important role in defining the capital structure of a PF venture. On the one hand, PF characterizes itself as a contracting and financing mechanism for facilitating equity investments into risky projects because it avoids or limits lenders to recur for repayment of their loans against the equity shareholders (Finnerty, 2007). On the other hand, the higher the risk, the lower the debt capacity of a project as a result of the reduced ability of a project to match financial covenants and, in particular, to meet the target Debt Service Coverage Ratio (DSCR). In fact, in high risk projects high interest rates are charged and reduced amount of loans are offered by lending institutions so that a higher target DSCR is assured to minimize the bank's risk-adverse commitment to the project. In other words, the amount of risks and the way such risks are being managed by the SPV impacts the project's capital structure, which is referred to as the level of equity and debt sources of funds required to cover the total initial investment.

Overall, the PF/BOT system has been being largely used to finance oil and gas infrastructure investments in many countries. Oil and gas projects typically require Corso Duca degli Abruzzi 24, 10129 Turin, Italy Tel: +39 0110907209 Fax: +39 0110907299 
large capitals with rather high level of risk to develop either upstream operations facilities, such as oil wells and offshore platforms, or downstream operations infrastructures, such as gas processing plants, oil refineries and pipelines. Oil and gas projects usually incur various risks, namely political, financial, revenue, construction and operations risks, which are quite similar to most risks faced by many types of projects in various industries. In addition, a distinctive risk that usually has a very high impact on oil and gas projects is the environmental risk, due to the inherent nature of petroleum operations to impact on the natural and human environment. The primary importance of environmental risk for oil and gas projects is testified by the amount of reported stories of oil spills, coastal degradation and communities concerns that often result in significant damages and economic losses suffered by the vehicle companies.

However, the environmental risk is often not given a considerable weight in analyzing the risk involved in a BOT project, resulting in an underestimation of the project's total riskiness and, in turn, in a potentially unbalanced capital structure.

A significant stream of literature is in the area of risk analysis and, in particular, on the relationship of project risk rating with the capital structure of a PF/BOT project (Baccarini and Archer, 2001). However, very little work seems to address the way that environmental risks affect the risk profile of a PF/BOT system (Grimsey and Lewis, 2002) in order to design an appropriate capital structure for an infrastructure investment. To overcome this research gap, the purpose of this research is to explore the dependence of the capital structure of $\mathrm{PF} / \mathrm{BOT}$ projects on environmental risk exposure and to propose a methodology for capturing environmental risk into the total risk profile of an oil and gas project and estimating its influence on the debt leverage.

The study is developed as follows. First, we give the literature review. Then, we present the methodology, followed by its application and validation on two case demonstration projects. Finally, we discuss results and draw conclusions together with implications and future research directions.

\subsection{Literature Review}

Previous relevant studies to understand the impact of environmental risk on the capital structure of $\mathrm{PF} / \mathrm{BOT}$ oil and gas projects can be subsumed into two main connected areas of management research.

The first research area is related to identifying and rating anticipated risks of a $\mathrm{PF} / \mathrm{BOT}$ project. It is commonly accepted in the project management literature that risk management is a central process requiring identification of various types of risks and assessment of the potential consequences and probability of occurrence of identified hazards (PMI, 2009; APM, 2004).

In particular, for the purpose of this study, the identification of risks that might have an impact on the financial structure of a PF/BOT infrastructure project is of crucial importance (Xenidis and Angelides, 2005) and various papers are available to identify the major risk categories, such as political, economic, financial, design, construction, supply, operating, revenue, force majeure and various other risks (Grimsey and Lewis, 2002; Svanikier, 2008; Marco et al., 2012). Some authors explicitly recognize environmental risk as a major source of hazard in PPP projects (Zhang, 2005b; Bing et al., 2005). Iyer and Sagheer (2010) describe environmental risks as those due to environmental impact liability, public protests and litigation by environmental activists that may occur during the construction and operation phases of the project. With specific regard to oil and gas projects, environmental risk is also referred to as oil and gas flaring, water pollution, threats to biodiversity with resulting compensation and restoration of livelihoods (Davis, 2003; Horta, 2007). From a financial point of view, environmental risk in oil and gas projects is seen as primarily related to potential changes to environmental regulations that could erode the project's credit stance and impact on the project cash flow.

As stated above, the risk rating of a PF/BOT project is a fundamental precursor to design the capital structure because it contributes to determining both the debt leverage and the interest rates on debt capital. Risk rating is usually determined through either qualitative or semiquantitative assessment of the combination of the probability of occurrence and impact of identified risks (PMI, 2009). The qualitative assessment is performed via range of nonnumeric notions (i.e., high, medium and low likelihood; catastrophic, medium and negligible impact), while semi-quantitative analysis can be defined when a scale factor is associated to nonnumeric ranking. Some researchers propose methods to rate the risk profile of a PPP project. Schaufelberger and Wipadapisut (2003) recommend a score from 1 to 5 for assessing political, financial and market risk of BOT projects, with 5 being very high risk,. They also provide evidence of the relationship between the risk profile and the equity to 
debt ratio of several projects under consideration. The same 1 to 5 scale is used by Baccarini and Archer (2001) to rank risk factors affecting project performance. We suggest using a 10 to 100 score for risk exposure of a project in different risk categories, with 100 being the most exposed. Standard and Poor's 2001 use a benchmark score of 1 to riskiest 10 when grading projects: generally, projects with score of 1 to 5 are investment-grade, while a score of 5 to 10 indicates speculative projects. Finally, Zayed et al. (2008) introduce a consistent procedure for assessing BOT project risks through the definition of a risk index and project ranking methodology using the analytic hierarchy process based on actual performance of eight main risk areas, i.e., political, financial, revenue, promoting, procurement, development, construction and operations risks.

Although environmental risk is paid attention in the risk identification literature, it seems that very little consideration is given to environmental risk by both scholarly and trade literature when rating the total risk profile of a BOT project. Claiming for the need of considering environmental risk into risk rating of PPP projects, the Equator Principles Financial Institutions (EPFIs, 2006) provide principles to ensure that projects are developed in a manner that are socially responsible and reflect sound environmental management practices and propose to rank projects into three categories, namely: (A) projects with potential significant adverse environmental impacts that are diverse, irreversible or unprecedented; (B) projects with potential limited adverse environmental impacts and $(\mathrm{C})$ projects with minimal or no environmental impacts. In conclusion, EPFIs tend to reject loans to A-class projects and limit loans to B-class projects.

The second pertinent area of management research is committed to develop suitable methodologies to optimize the PF capital structure and, in particular, to define the debt leverage via financial covenants like the DSCR. In fact, professional practice and previous research have found evidence that the DSCR, which reflects the project's debt carrying ability, is the lender's most sound indicator for establishing the debt leverage (Bakatjan et al., 2003). DSCR is referred to as the amount of cash flow available to meet annual interest and principal payments on debt, including any sinking fund payments and it is computed as the ratio between operating cash flow and debt service during a one-year period (Esty, 2004). Generally, the DSCR should be at least equal to or greater than 1.0 to be acceptable, but lending agencies actually demand higher and a more comfortable target DSCR up to 1.5 , according to the anticipated risk exposure (Zhang, 2005a). In other words, the target DSCR is set at high levels whenever a high risk score is assessed for the project.

In summary, even though risk is affirmed to be central in the definition of the DSCR and, in turn, of the optimal capital structure and risk taxonomies are provided that contemplate environmental risk, little previous work is reported with focus on the influence of environmental risk on the PF capital structure. Also, it seems that environmental risk is not fully considered in the total risk assessment procedure used by lending and rating institutions. However, environmental risk might be of great impact particularly for oil and gas projects.

To overcome this limitation and understand the extent to which environmental risk might influence the PF capital structure, in the next sections we develop a methodology that integrates environmental risk into project rating and capital structuring and we provide its application and measurement to two oil and gas demonstration projects.

\section{MATERIALS AND METHODS}

The proposed methodology comprises four main steps, namely: (1) identification and semi-quantitative rating of the project's total risk exposure; (2) determination of the appropriate interest rate through the Capital Asset Pricing Model (CAPM); (3) calculation of the DSCR and (4) estimation of project's debt-to-equity ratio. Figure 1 depicts the process flow for determining the debt leverage and shows how the computation of the DSCR and debt leverage are iterative until the final satisfactory debt service ability is obtained.

\subsection{Step 1. Risk Identification and Rating}

Step Based on models available in the literature to classify risks in PPP contracts (Schaufelberger and Wipadapisut 2003; Xenidis and Angelides, 2005; Zhang 2005b; Iyer and Sagheer, 2010), typical risks inherent with oil and gas BOT projects, including environmental risk, are identified using a Risk Breakdown Structure (RBS) (PMI, 2009), like the one presented in Fig. 2.

Identified risks are then assessed their impact of consequences and likelihood of occurrence. A semiquantitative risk analysis is used by assigning numerical scores to nonnumeric definitions of each of these constituents, as shown in Table $\mathbf{1}$ and 2 . In particular, a scale from 1 to 5 is assigned to the probability of risk events and a grading from 1 to 10 is applied for evaluating the impact of consequences. 


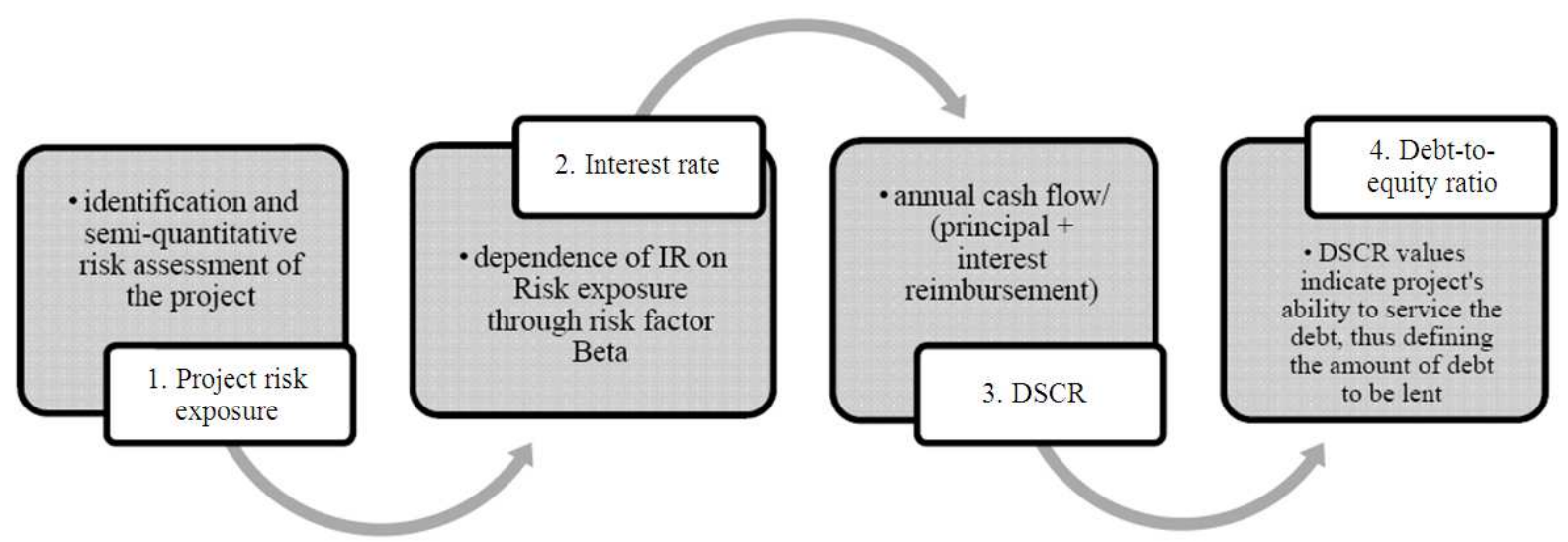

Fig. 1. Methodology flow chart

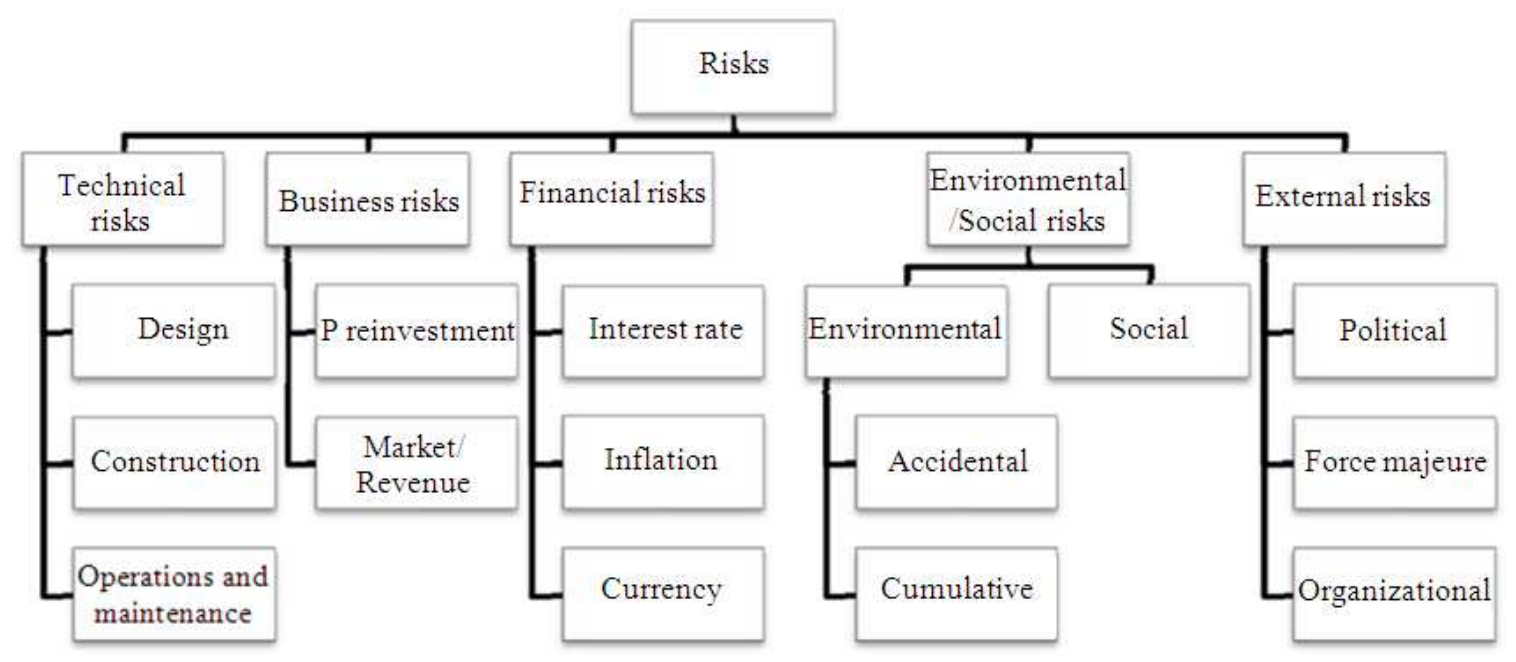

Fig. 2. Proposed risk breakdown structure for an oil and gas BOT project

Table 1. Likelihood scores

\begin{tabular}{ll}
\hline Score & Description \\
\hline 1 & Very low-almost never happened in industry \\
2 & Low-happens rarely \\
3 & Medium \\
4 & High-likely to happen \\
5 & Very high-almost certain to happen \\
\hline
\end{tabular}

Table 2. Impact scores

\begin{tabular}{ll}
\hline Score & Description \\
\hline $0-2$ & Insignificant \\
$3-4$ & Minor \\
$5-6$ & Moderate \\
$7-8$ & Major \\
$9-10$ & Catastrophic \\
\hline
\end{tabular}

Table 3. Risk categories weight without incorporation of environmental risk

\begin{tabular}{lc}
\hline Risk category & Weight \\
\hline Technical (Technology, & \\
construction and operational) & 0.20 \\
Business (Market and revenue) & 0.25 \\
Financial & 0.35 \\
External & 0.20 \\
\hline
\end{tabular}

A committee of experts is recommended to make the grading in order to limit subjective preference and individual's judgment (Zayed and Chang, 2002).

The weight of each risk category is then determined. The weight of a group of risks reflects its importance relative to the other categories, irrespective of any particular project. 
Table 4. Risk categories weight with incorporation of environmental risk

\begin{tabular}{lll}
\hline Risk category & Weight & Description \\
\hline Technical & 0.17 & $\begin{array}{l}\text { In petroleum industry it is typical to conduct operations in remote areas and offshore; } \\
\text { harsh conditions may present great risk despite possible mitigation measures, therefore, the } \\
\text { weight of this risk group is higher than of Financial risks that are relatively easy to be } \\
\text { managed, but lower than of Business, External and Environmental. } \\
\text { Business risk group which comprise P reinvestment and Market risks has a higher eight } \\
\text { than Financial and Technical risk groups, because of the peculiarity of the industry: high } \\
\text { volatility of prices and commodity risk. An approximate cost of conducting a 3D seismic } \\
\text { survey is millions of dollars, yet it does not guarantee the presence of oil for 100\%. }\end{array}$ \\
$\begin{array}{lll}\text { Financial } \\
\text { Financial markets have learnt to manage such risks better than others; therefore, the weight } \\
\text { is the lowest. }\end{array}$ \\
$\begin{array}{l}\text { Environmental } \\
\text { Environmental }\end{array}$ & 0.20 & $\begin{array}{l}\text { Each step of petroleum operations have an adverse effect on environment, therefore, } \\
\text { the importance of this risk group is the highest relative to other groups. }\end{array}$ \\
Accidental & 0.3 & $\begin{array}{l}\text { Accidental risks have greater impact than cumulative when they occur, but people are } \\
\text { aware of such risks and are able to manage them. } \\
\text { Cumulative risks occurrence is almost certain; their impact is observed in long-term, } \\
\text { usually not taken seriously. }\end{array}$ \\
$\begin{array}{l}\text { Social } \\
\text { External }\end{array}$ & 0.3 & $\begin{array}{l}\text { Force majeure risks cannot be managed by any party, politics play a significant role in } \\
\text { petroleum industry and thus the weight is the same as for Business risk group. }\end{array}$ \\
\hline
\end{tabular}

In general, the choice of the risk weight is quite subjective and relies on the principle that the better the hedging methods available for avoiding or mitigating the effects of a certain risk in the market/industry, the lower their influence on the risk profile yielding in a lower relative weight. With this principle in mind and based on practices from international rating agencies we propose a weighing system for identified risk categories experienced in oil and gas BOT projects (Table 3).

This weighing method does not consider environmental risks. To overcome this limitation and adjust the weights to the suggested RBS presented in Figure 2, we propose a derivative weighing system, which incorporates environmental risks. The complete weighing system is presented in Table $\mathbf{4}$ with justification of relative weight assigned to each category.

The two case scenarios, namely (a) with incorporation of environmental risk and (b) without considering environmental risk, can now be compared. The computation of the project's exposure to all risks, i.e.: the project risk $\mathrm{s}$, is proposed as follows.

The exposure $\mathrm{R}_{\mathrm{i}}^{\text {ne }}$ of any group of risks, except for the environmental group, is calculated through Equation 1:

$$
\mathrm{R}_{\mathrm{i}}^{\mathrm{ne}}=\mathrm{L} * \mathrm{I}
$$

Regarding the risk exposure of the environmental risk group $\mathrm{R}_{\mathrm{i}}^{\mathrm{e}}$, a modified Equation 2 is used it to account for the community risk perception, which weighs the impact factor more than the likelihood (Carpignano et al., 2009):

$$
\mathrm{R}_{\mathrm{i}}^{\mathrm{e}}=\mathrm{L}^{*} \mathrm{I}^{\mathrm{k}}
$$

where, $\mathrm{k}>1$; for instance, in more community-sensitive countries $\mathrm{k}$ might equal 2.0 to stress the importance of the adverse impact of risk.

Burgman (2005) states that risk can be underestimated by the risk proponents and overestimated by those dealing with the consequences. Nevertheless, the degradation of ecosystems due to petroleum operations is taking place on a global scale and environmental awareness is arising, thus increasing community's susceptibility to possible adverse effects. This is why it is proposed to weigh the impact from environmental risk more than impacts from other risk groups.

For the sake of simplicity, only the first level risks of the RBS are being considered, except for the environmental risks, where both second and third levels are taken into account (Table 4).

Finally, the total risk rating $\mathrm{R}$ of the project is computed as the summation of each risk group exposure $\mathrm{R}_{\mathrm{i}}$ times the correspondent weight $\mathrm{W}_{\mathrm{i}}$, as given in Equation 3:

$\mathrm{R}=\sum \mathrm{R}_{\mathrm{i}} * \mathrm{~W}_{\mathrm{i}}$

\subsection{Step 2. Interest Rate Calculation}

There are a number of factors that might affect the interest rate on loans for a PPP project. Firstly, interest rates are strongly influenced by the overall condition of a 
country's economy. When the economy is growing, the consumers' demand for goods increases leading to increase in demand for funds and interest rate rise and viceversa. Inflation also affects interest rates to compensate lenders for the decreased future value of money. Taxes may also be a reason for higher rates because some of the gains from interest may be subject to taxes and the lender may insist on a higher rate to make up for this loss. As anticipated earlier into this study, another factor affecting interest rates is the risk profile of the project: the riskier the project, the higher the rate offered by lending institutions. To prove this relationship the Capital Asset Pricing Model (CAPM) is applied in our methodology. Some important assumptions are made prior using the model.

First of all, theoretically, CAPM is used when defining the cost of capital of a firm, not a single project. Application of CAPM in calculating the interest rate offered for a project could be justified by the fact that, as the analyzed projects were financed by means of PF, they were developed by SPV companies created exclusively for the purpose of this project. Thus, the CAPM in PF could be used directly to identify the expected rate of return of a project.

The CAPM states that the equilibrium rate of return of an asset, or a project, is function of the relative risk level when compared to the market portfolio and can be computed with Equation 4:

$$
\mathrm{E}\left(\mathrm{r}_{\mathrm{i}}\right)=\mathrm{r}_{\mathrm{f}}+\beta_{\mathrm{i}} *\left[\mathrm{E}\left(\mathrm{r}_{\mathrm{m}}\right)-\mathrm{r}_{\mathrm{f}}\right]
$$

where, $E\left(r_{i}\right)$ is the expected return of the project; $r_{f}$ the risk-free interest rate at the same period, such as a government bond or Treasury bill rates; $\mathrm{E}\left(\mathrm{r}_{\mathrm{m}}\right)$ the expected return of the market, with the S\&P500 index widely used as a benchmark; $\left[\mathrm{E}\left(\mathrm{r}_{\mathrm{m}}\right)-\mathrm{r}_{\mathrm{f}}\right]$ the excess rate of return on the market portfolio; the product $\beta_{\mathrm{i}}{ }^{*}\left[\mathrm{E}\left(\mathrm{r}_{\mathrm{m}}\right)-\mathrm{r}_{\mathrm{f}}\right]$ indicates the risk premium; and $\beta_{\mathrm{i}}$ the systematic risk of the project. In classical theory, an asset that has $\beta>1$ is more sensitive to market movements than the market portfolio, thus more risky and should provide greater returns than the expected return on the market portfolio. Similarly, an asset with $\beta<1$ is less risky than the market portfolio).

Now, because data for extrapolating $\beta$ of a single project are not available, we propose to use Equation 5 to calculate the project beta:

$$
\beta=\mathrm{R} / 100+1
$$

where, $\mathrm{R}$ is the overall project risk rating.

This formula is used for the purpose of this study when analyzing oil and gas projects. As one can conclude, oil and gas projects would thus be riskier than the overall PPP infrastructure market, as values of beta calculated with such formula are be greater than 1.0.

Obviously, the calculated values of risk rating affect the value of beta, which has, in turn, an impact on the debt interest rate; it is expected that greater values of beta yield higher interest rate.

\subsection{Step 3. DSCR Calculation}

After determining the risk exposure and the interest rate, it is possible to compute the $\mathrm{DSCR}_{\mathrm{y}}$ in any one single year of operations, using Equation 6:

$$
\operatorname{DSCR}_{\mathrm{Y}}=\text { net cash flow }_{\mathrm{y}} /(\text { principal }+ \text { int erest })_{\mathrm{y}}
$$

The amount of debt the project is able to service depends on the annual net cash flow generated by the project operations, the debt principal to be reimbursed and the interest charged by the banks' pool. The minimum DSCR in the worst-case year must be greater than the target DSCR imposed by lending institutions. The target DSCR is a function of the estimated project's total risk score.

\subsection{Step 4. Estimation of the Debt Leverage}

Finally, the capital structure is defined according to the bank's requirements of targeting DSCR values. The impact of the risk rating on the DSCR occurs in two ways: on the one hand, the higher the risk, the greater the interest rate offered by the bank and, thus, for a given amount of cash flow and debt, lower values of DSCR are obtained. On the other hand, as banks are risk averse organizations, they tend to increase their target requirements on the DSCR in case the debt risk exposure is high. Thus, there are low chances of matching the required financial covenants.

There are two possible solutions when the resulting DSCR falls below the target established by the bank as a function of the risk assessed. A first solution provides for lending institutions to decrease the loan amount, so that the capital structure would result in a lower debt-toequity ratio.

Table 5. Select parameters for the demonstration projects

\begin{tabular}{lllll}
\hline & Project \#1 & \multicolumn{2}{l}{ Project \#2 } \\
\cline { 2 - 5 } & Case (a) & (b) & (a) & (b) \\
\hline $\begin{array}{l}\text { Environmental } \\
\text { risk exposure }\end{array}$ & 40.88 & - & 70.13 & - \\
$\begin{array}{l}\text { Project total } \\
\text { risk rating }\end{array}$ & 54.68 & 18.1 & 85.64 & 21.35 \\
$\begin{array}{l}\text { Annual } \\
\text { interest rate }\end{array}$ & $8.15 \%$ & $7.24 \%$ & $8.92 \%$ & $7.32 \%$ \\
Minimum DSCR & 4.21 & 4.22 & 1.29 & 2.11 \\
\hline
\end{tabular}


Table 6. Project\#1 cash flow data

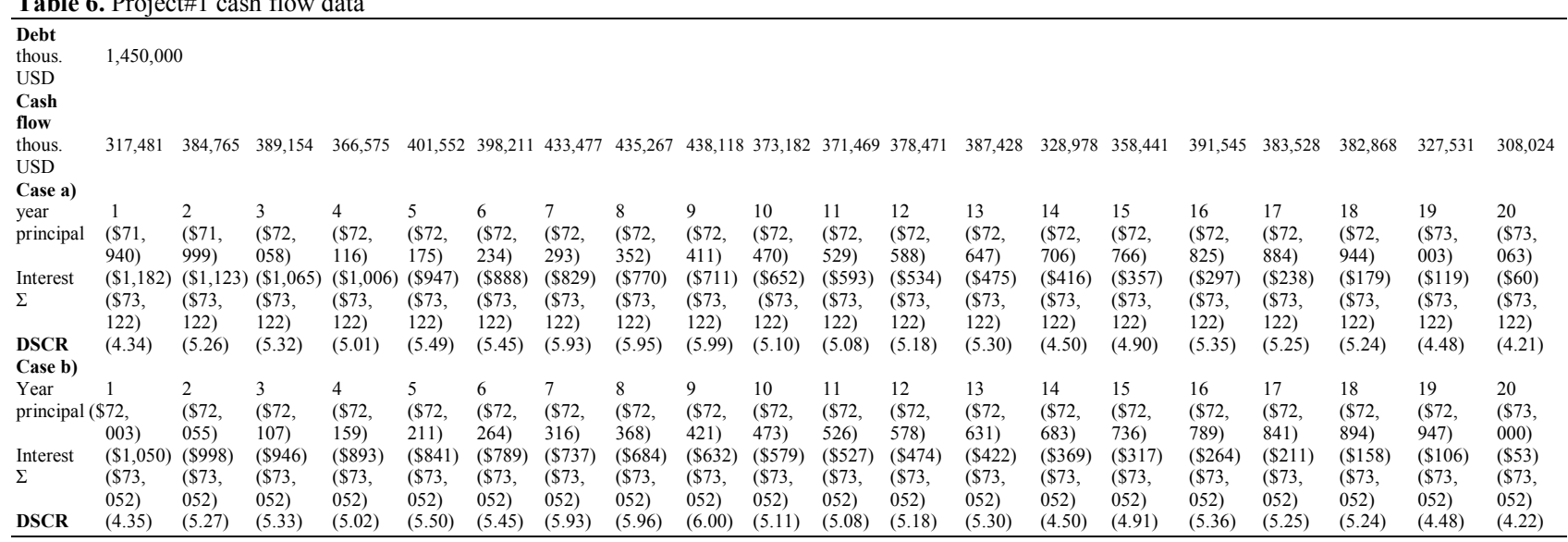

Table 7. Project \#2 cash flow data

\begin{tabular}{|c|c|c|c|c|c|c|c|c|c|c|c|c|c|c|}
\hline $\begin{array}{l}\text { Debt } \\
\text { thous. } \\
\text { USD }\end{array}$ & $1,400,000$ & & & & & & & & & & & & & \\
\hline $\begin{array}{l}\text { Cash } \\
\text { flow } \\
\text { thous. } \\
\text { USD }\end{array}$ & 433,000 & 894,000 & $1,007,000$ & $1,002,000$ & $1,024,000$ & $1,019,000$ & 826,000 & 642,000 & 470,000 & 376,000 & 324,000 & 281,000 & 244,000 & 212,000 \\
\hline Case a) & & & & & & & & & & & & & & \\
\hline Year & 1 & 2 & 3 & 4 & 5 & 6 & t & 8 & 9 & 10 & 1 & 12 & 13 & 14 \\
\hline Principal & $(\$ 54,109)$ & $(\$ 58,937)$ & $(\$ 64,195)$ & $(\$ 69,923)$ & $(\$ 76,162)$ & $(\$ 82,957)$ & $(\$ 90,359)$ & $(\$ 98,421)$ & $(\$ 107,202)$ & $(\$ 116,767)$ & $(\$ 127,185)$ & $(\$ 138,533)$ & $(\$ 150,894)$ & $(\$ 164,357)$ \\
\hline Interest & $(\$ 1,249)$ & $(\$ 1,16$ & $(\$ 1,07$ & (\$983) & $(\$ 894)$ & $(\$ 805)$ & $(\$ 716)$ & (\$627) & (\$537) & $(\$ 448)$ & $(\$ 358)$ & $(\$ 269)$ & (\$179) & (\$90) \\
\hline$\Sigma$ & $(\$ 55,358)$ & $(\$ 60,097)$ & $(\$ 65,267)$ & $(\$ 70,906)$ & $(\$ 77,055)$ & $(\$ 83,762)$ & $(\$ 91,074)$ & $(\$ 99,047)$ & $(\$ 107,739)$ & $(\$ 117,215)$ & $(\$ 127,544)$ & $(\$ 138,802)$ & $(\$ 151,073)$ & $(\$ 164,447)$ \\
\hline DSCR & (7.82) & (14.88) & (15.43) & (14.13) & (13.29) & (12.17) & $(9.07)$ & (6.48) & (4.36) & (3.21) & (2.54) & $(2.02)$ & $(1.62)$ & (1.29) \\
\hline & & & & & & & & & & & & & & \\
\hline Year & 1 & 2 & 3 & 4 & 5 & 6 & 7 & 8 & 9 & 10 & 1 & 12 & 13 & 14 \\
\hline Principal & $(\$ 99,525)$ & $(\$ 99,598)$ & $99,671)$ & $(\$ 99,744)$ & $(\$ 99,817)$ & $(\$ 99,890)$ & $(\$ 99,963)$ & $(\$ 10$ & $(\$ 100,109)$ & $(\$ 100,183)$ & $(\$ 100,256)$ & $(\$ 100,329)$ & $(\$ 100,403)$ & $(\$ 100$ \\
\hline Interest & $(\$ 1,025)$ & $(\$ 952)$ & (\$879) & $(\$ 806)$ & $(\$ 733)$ & $(\$ 660)$ & $(\$ 587$ & $(\$ 514$ & (\$44 & $(\$ 367)$ & $(\$ 29$ & (\$221) & (\$147) & $(\$ 74)$ \\
\hline$\Sigma$ & $(\$ 100,550)$ & $(\$ 100,550)$ & $(\$ 100,550)$ & $(\$ 100,550)$ & $(\$ 100,550)$ & $(\$ 100,550)$ & $(\$ 100,550)$ & $(\$ 100,550)$ & $(\$ 100,550)$ & $(\$ 100,550)$ & $(\$ 100,550)$ & $(\$ 100,550)$ & $(\$ 100,550)$ & $(\$ 100,550)$ \\
\hline DSCR & (4.31) & (8.89) & $(10.01)$ & $(9.97)$ & (10.18) & (10.13) & $(8.21)$ & (6.38) & (4.67) & (3.74) & $(3.22)$ & $(2.79)$ & $(2.43)$ & (2.11) \\
\hline
\end{tabular}

However, the SPV's sponsors usually seek to maximize the debt leverage of the project in order to minimize their equity participation in the project and associated risk, to maximize the internal rate of return to equity and to allocate limited money in multiple projects (Zhang, 2005b). Thus, a second option suggests that project promoters take preventive risk mitigating actions to lower the risk exposure of the project in order to obtain less interest rate and to take advantage of larger loan amounts.

\subsection{Application}

For the purpose of validating and proving the viability of the proposed methodology, we apply it to two oil and gas BOT projects, whose names and location cannot be disclosed for confidentiality reasons. The projects under consideration are real past ventures used here as a demonstration. Project \#1 comprises design, construction and operations of an oil field development, a pipeline system and downstream facilities. Environmental risks borne by Project \#1 are mainly air emissions and oil spills; these are amplified by the specific properties of the hydrocarbons such as high concentration of sulphur and metals, particularly nickel and vanadium. Their processing implies a coke and sulphur generation, as well as a large amount of effluents and emissions to the atmosphere. Pipelines are laid under the sea, thus, discharges of oil and chemicals have various lethal and non-lethal effects on maritime wildlife. Moreover, the onshore part of the pipeline is laid underground which demands for a considerable earth disruption.

Project \#2 consists of two components: a field system comprising drilling of wells to extract oil, a treatment facility to upgrade oil, an operating center for production support; and an export system which entails a pipeline from the oil fields to a floating storage, an offloading vessel located offshore and a monitoring system to detect potential oil leaks. Project \#2 is executed in a sensitive area consisting of a number of rivers, habitat zones where rare plants and endangered species live and a delicate marine environment; moreover, the pipeline crosses a huge littoral forest zone. Thus, environmental risks such as oil spills, deforestation and degradation of coastal reef are encountered by the construction and operations activities; air pollution is 
also a concern. It must be noted that the probability of these risks to occur and, consequently, the possible impact on the environment and people, is very high and in some cases almost inevitable due to the peculiarities of politics and attitude of different parties executing the project.

It is expected that higher risk exposure would lead to lower minimum DSCR, all other components remaining equal. This would indicate the inability of a project to service its debt in case the minimum DSCR falls below the target DSCR imposed by the bank.

Cash flow data used for DSCR computations of both projects are reported in Table 6 and 7.

\section{RESULTS}

Table 5 is a summary report of the two projects' risk score, annual interest rate and minimum DSCR figures. We calculated all parameters using the steps of the proposed methodology and under both case scenarios above, namely: (a) with environmental risk rating; (b) without considering environmental risk.

For both projects, an increased case (a) risk rating than case (b) is due to the incorporation of environmental risks into the risk assessment, which, theoretically, affects the capital structure of the project. However, a different impact of environmental risk exposure on the two proposed projects results in differing influence on the minimum DSCR. For project \#1, which bears a low level of environmental risk exposure, the difference is insignificant and clearly does not increase the interest charged and, in turn, does not affect the capital structure of the project.

For Project \#2, the difference in minimum DSCR between the two cases is due to a high environmental risk exposure of the project. In particular, the project fails to meet a typical 1.5 target DSCR when environmental risk is added, while without the effect of environmental considerations the project cash flow is largely capable to bear the expected debt. Therefore, a lower debt-to-equity ratio must be determined.

In summary, the debt service ability of each project depends on the level of risk exposure borne by associated performed construction and operations: here, project \#2 has much greater potential effect on the environment than project \#1. For the same values of cash flow and debt, the minimum DSCR decreases with increased risk exposure. The main reason is the increase in the interest rate, which in turn is the indicator of a bank's willingness to provide financing to risky projects: the higher the risk, the higher the expected return. Also, if risk is not mitigated and the total risk profile is not improved, the debt leverage is likely to be reduced, thus leading to a higher equity level.
The methodology poses some limitations inherent with its domain of application and level of profitability. As stated above, environmental risk is not just the only factor influencing the DSCR. Therefore, the advantages of the proposed methodology are maximized when it is applied to those sectors and projects characterized by high environmental risks. In such cases, the difference in total risk exposure would be more significant and so would be its impact on the DSCR.

Also, projects with non-maximized debt leverage may be insensitive to variations in the DSCR and, therefore, insensible to environmental risk exposure. For instance, project \#1 expects to generate cash flows high enough to service even greater debt than established, so that a reduced minimum DSCR does not have much impact on the financial structure.

\section{DISCUSSION}

The preventive actions conducted to mitigate the environmental risk exposure are likely to affect the project's capital structure in two ways. On the one hand, a lower environmental risk contributes to reducing the overall risk score of the project with subsequent reduced interest, higher minimum DSCR, lower target DSCR and, in turn, higher debt leverage and reduced equity contribution to the total investment.

On the other hand, the costs of risk mitigating actions undertaken during the design and construction periods result in an increased initial investment either through increased equity, which leads to lower debt-to equity ratio, or by acquiring more debt, if the project cash flow and minimum DSCR can justify.

Improved risk mitigation actions include, but are not limited to, implementation of more advanced technologies, systems and processes that might lead to less negative impact on the environment and improved safety. However, because huge research and development (R\&D) efforts are usually required in relation to such advancement in risk-preventive technologies and because lending institutions are disinclined to finance risky and unprofitable $R \& D$ spending for environmental risk mitigating measures, it may be concluded that oil and gas companies have to fund the development of advanced environmental technologies with owned equity sources.

At a first glance, such scenario might seem unattractive to oil and gas players. Companies are reluctant to invest much equity in the project due to the reasons discussed above. 
However, the situation is changing. Besides traditional consequences from environmental risks such as increased operating costs and penalties, many emerging social and environmental pressures associated with requirements on greenhouse gas emissions reduction, boicott campaigns and opposition by environmentalists, are likely to increasingly affect oil and gas shareholders' value, project risk management policies and BOT/PF options (Wright and Rwabizambuga, 2006). Moreover, the ever increasing significance of the health, safety and environment management systems has been leading oil and gas contractors to place the implementation of such systems in their agenda. Therefore, both investing equity resources to sustain $R \& D$ investments to mitigate environmental risk and accounting for the impact of environmental risk into the project total risk rating are necessary trends to facilitate an appropriate debt leverage into BOT/PF oil and gas projects. The proposed methodology can help oil and gas companies in this process.

This study also promises applicability to other sectors and might be beneficially used as a template for an investigation in other infrastructure projects that are, to some extents, exposed to high environmental risks. To this end, future research should extend the validity of the methodology beyond the oil and gas context and generalize its results for diffused usage by lending institutions and concessionaires.

\section{CONCLUSION}

In the current practice the share of environmental risks in the assessment of the total risk profile of an oil and gas BOT/PF project is often underestimated. However, environmental risks pose a significant threat to the project financial viability. Thus, environmental risks must be given an appropriate weight when defining the risk profile of a project. To this end, this study proposes a methodology for incorporating environmental risks into the project total risk rating and for refining the process to determine the capital structure of a BOT/PF investment.

Through application to two case studies, it has been shown that higher values of risk exposure due to environmental risks lead to increased interest rates offered by lending institutions, decreased debt service ability of the project's cash flows and, as a result, a lower debt leverage. It is also shown that low levered projects may be not affected by variations of the risk score due to high environmental risk exposure. However, because of reduced equity availability, the capital structure of BOT/PF projects tends to maximize the debt leverage and, consequently, be highly exposed to the consequences of environmental risks.

\section{REFERENCES}

APM, 2004. Project Risk Analysis and Management Guide. Association for Project Management. 2nd Ed. APM Publishing Limited, U.K., ISBN-10: 1903494125, pp: 186.

Baccarini, D. and R. Archer, 2001. The risk ranking of projects: A methodology. Int. J. Project Manage., 19: 139-145. DOI: 10.1016/S0263-7863(99)00074-5

Bakatjan, S., M. Arikan and R.L.K. Tiong, 2003. Optimal capital structure model for BOT power projects in Turkey. J. Constr. Eng. Manage., 129: 89-97. DOI: 10.1061/(ASCE)07339364(2003)129:1(89)

Bing, L., A. Akintoye, P.J. Edwards and C. Hardcastle, 2005. The allocation of risk in PPP/PFI construction projects in the UK. Int. J. Project Manage., 23: 2535. DOI: 10.1016/j.ijproman.2004.04.006

Burgman, M., 2005. Risks and Decisions for Conservation and Environmental Management. 1st Edn., Cambridge University Press, Cambridge, U.K., ISBN-10: 0521543010, pp: 448.

Carpignano, A., E. Golia, C. Di Mauro, S. Bouchon and J.P. Nordvik, 2009. A methodological approach for the definition of multi-risk maps at regional level: First application. J. Risk Res., 12: 513-534. DOI: 10.1080/13669870903050269

Davis, H.A., 2003. Project Finance: Practical Case Studies. 2nd Ed. Euromoney Books, London, ISBN10: 1855648458 , pp: 285.

EPFIs, 2006. The equator principles. EP.

Esty, B.C., 2004. Modern Project Finance: A Casebook. 1st Edn., John Wiley and Sons Ltd, New York, ISBN-10: 0471434256, pp: 562.

Finnerty, J.D., 2007. Project Financing: Asset-Based Financial Engineering. 2nd Edn., John Wiley and Sons, New York, ISBN-10: 0470086246, pp: 496.

Grimsey, D. and M.K. Lewis, 2002. Evaluating the risks of public private partnerships for infrastructure projects. Int. J. Project Manage., 20: 107-118. DOI: 10.1016/S0263-7863(00)00040-5

Horta, K., 2007. The chad-cameroon oil and pipeline project. Center for Environment and Development.

Iyer, K.C. and M. Sagheer, 2010. Hierarchical structuring of PPP risks using interpretative structural modeling. J. Constr. Eng. Manage., 136: 151-160. DOI: 10.1061/(ASCE)CO.19437862.0000127 
Marco, A.D., G. Mangano and X.Y. Zou, 2012. Factors influencing the equity share of build-operate-transfer projects. Built Environ. Project Asset Manage., 2: 70-85. DOI: $10.1108 / 20441241211235062$

PMI, 2009. Practice Standard for Project Risk Management. 1st Edn., Project Management Institute, Newtown Square, ISBN-10: 193389038X, pp: 116 .

Schaufelberger, J.E. and I. Wipadapisut, 2003. Alternate financing strategies for build-operate-transfer projects. J. Constr. Eng. Manage., 129: 205-213. DOI: 10.1061/(ASCE)0733-9364(2003)129:2(205)

Svanikier, V., 2008. Power projects: How does risk management affect its value? University of Dundee.

Wright, C. and A. Rwabizambuga, 2006. Institutional pressures, corporate reputation and voluntary codes of conduct: An examination of the equator principles. Bus. Soc. Rev., 111: 89-117. DOI: 10.1111/j.1467-8594.2006.00263.x

Xenidis, Y. and J. Angelides, 2005. The financial risks in build-operate-transfer projects. Constr. Manage. Econ., 23: 431-441. DOI: $10.1080 / 01446190500041552$
Zayed, T., M. Amer and J. Pan, 2008. Assessing risk and uncertainty inherent in Chinese highway projects using AHP. Int. J. Project Manage., 26: 408-419. DOI: 10.1016/j.ijproman.2007.05.012

Zayed, T.M. and L. Chang, 2002. Prototype model for build-operate-transfer risk assessment. J. Manage. Eng., 18: 7-16. DOI: 10.1061/(ASCE)0742$597 X(2002) 18: 1(7)$

Zhang, X., 2005a. Financial viability analysis and capital structure optimization in privatized public infrastructure projects. J. Constr. Eng. Manage., 131: 656-668. DOI: 10.1061/(ASCE)07339364(2005)131:6

Zhang, X., 2005b. Concessionaire's financial capability in developing build-operate-transfer type infrastructure projects. J. Constr. Eng. Manage., 131: 1054-1064. DOI: 10.1061/(ASCE)07339364(2005)131:10(1054)

Zhang, X., 2009. Win-win concession period determination methodology. J. Constr. Eng. Manage., 135: 550-558. DOI: 10.1061/(ASCE)CO.1943-7862.0000243 